Rev. Bruce R. Barnes

International Institute for Hermeneutics

DOI: $10.15290 /$ rtk.2021.20.01

iD $0000-0003-4848-9821$

\title{
The Noahide Laws and the Universal Fellowship with God
}

This article presents the possibility of a theory of natural law in Judaism from the Jewish perspective by listening to the Jewish tradition of scholarship on religion and philosophy. The first part of this paper is concerned with evidence for a theory of natural law in Judaism. It centers around the Noahide Laws and their influence on Gentile and pre-Simatic Judaism. The second part deals with Moses Maimonides and his ideas concerning the interpretation of natural law for Jews. The third part discusses Jewish scholars who have refuted the work of Maimonides and proposed various theories of natural law. They have been a consistent part of Jewish tradition and provide a path, however narrow, along which Jews may travel towards participation in global issues and work among non-Jewish people.

Keywords: natural law, Moses Maimonides, the Noahide Laws, classical Islamic philosophy, ecumenical dialogue.

The possibility of a theory of natural law in Judaism may seem strange to both Christian and Jewish scholars alike. It is certainly not surprising as the most critical event of law-giving centered on the great theophany on Mount Sinai. Two main factors have influenced scholars to decry or ignore the possibility of a natural law theory in Judaism. The first is the belief that every law in Judaism is traditionally conceived as a revelation. The second is the impact of one of the greatest Jewish medieval philosophers and theologians, Moses Maimonides (1135-1204), also known Rambam.

The impact of Maimonides' writings and thoughts are common to all branches of Judaism. Orthodox Judaism, however, holds him in the highest regard. Within this branch of Judaism, his codification of the 
Biblical Hermeneutics

law, holiness, and fervor have earned him a place at the heart of Jewish faith and its interpretation, but he does not have sole jurisdiction over the subject. There is a steady line of scholars who have disputed with Maimonides down the ages. From the rise of Reformed Orthodox Judaism in the nineteenth century, scholars have undertaken a serious reassessment of Maimonides' works, particularly his ideas concerning law and morality. Within this framework, natural law has also been reassessed and continues to be part of contemporary debate within Judaism.

This paper presents the Jewish, and not Christian, perspective. The author places himself within the Jewish tradition of scholarship by listening to Jewish philosophers in order to answer Jewish questions. ${ }^{1}$ This work might promote cooperation, dialogue, and understanding among Christians and Jews in fundamental moral theology. If natural law is acknowledged within Judaism and becomes recognizable, then a further dimension can be affirmed in developing Jewish-Christian dialogue. In a published document by the Catholic Bishops Conference of England and Wales, natural law is singled out as a quality that can serve the common good and further a growing understanding between the two great religious traditions:

The interpretation of natural law is rarely straightforward and often controversial. It is easier to say that natural law points to the need for an harmonious and balanced order than to say in any particular case exactly where the balance is to be found... to ignore natural law, for instance, by organising society so that in effect it serves the interests of a few rather than the common good, is to collaborate with the structures of $\sin ^{2}$

\section{The Noahide Laws as a Basis for a Theory of Natural Law in Judaism}

Theories of natural law contain two essential elements. The first is a general or universal (natural) standard that can serve as the basis for society's conduct and normative acts. They are founded upon more binding and permanent principles than custom, convention, or human

\footnotetext{
1 The author wishes to thank the Jewish student community of The Jews College, Golders Green, which is part of the university of London as well as the college librarian, Mr. Khan.

2 "The Common Good and the Catholic Church's Social Teaching: A Statement by the Catholic Bishop's Conference of England and Wales," 1996, https://cbcew. org.uk/plain/wp-content/uploads/sites/3/2018/11/common-good-1996.pdf.
} 
agreement. The second is that these natural standards can be used as criteria by which particular laws or legal codes can be judged or in which they can be grounded. The claims of these standards provide the criteria to which a person can appeal as a higher standard of justice than that which is contained in a particular legal code. They are the basis for resolving legal questions when the existing legal code does not provide legislation regarding a particular problem. Any serious investigation seeking a natural law theory in the Jewish scriptures must have these claims as a backdrop. The Jewish legal code extends beyond the written text known in the Christian tradition as the Pentateuch and includes the rabbinic oral tradition and rabbinic written texts. Within the rabbinic tradition, it is possible to support a theory of natural law based on the Noahite or Noahide Laws.

\section{Implicit in Scripture}

There is no support in the Jewish scriptures for the term natural law, and it has no corresponding Jewish equivalent in the text. In the rabbinic texts, the closest reference to nature is the expression, "the world follows its own habit." This suggests that events typically occur in a pattern established under Divine Providence. Still, it was not until the Middle Ages that the Hebrew word teva ("implant" or "impression") was coined to express the idea that nature is the order that God impressed on His creation. A later development of the word - ha-teva, "the nature"-identifies nature with God. There have been Jewish thinkers who recognized the notion of natural law, and there have been non-Jewish writers concerned with the idea. ${ }^{3}$ However, in Judaism there is a deep-seated antipathy to any theory of natural law because it would be considered a form of questioning God's omnipotence.

Indeed, there is a lack of reference to natural law in scripture that reinforces the argument of those who oppose such a theory. They develop their argument by suggesting that a theory of natural law is probing God's omnipotence. This argument employs a literal interpretation of scripture which suggests that no independent laws of nature are possible. This ultimately confirms God's omnipotence because everything must be subject to His absolute authority. The lack of scriptural authority is an indication that God, Himself, does not sanction this form, which Jeffrey Macey summarizes in his book Natural

3 The Dutch scholar Hugo Grotius' (1583-1645) work De Veritate Religionis Christianae \& De Juri Belli ac Pacis, examines the question of natural law in the Pentateuch. See also John Seldon, De Joe Naturalis et Gentium Juxta Disciplinam Ebracorum, Argentorati, Sumptibus Societatis, 1665. 
Biblical Hermeneutics

Law: "Thus, the lack of independent laws of nature and the emphasis upon divine creation and control of everything that exists and occurs highlights the position that everything in our world is subject to the absolute authority of God and is responsive to His will."4

Questioning God's omnipotence is also seen as damaging to the God of history, and, within this context, it also becomes a threat to the law. For, God has continual power over creation and gives a perfect law, which is ratified by God's right to punish those who transgress the law. It is His prerogative alone. In this case, there is no room for an independent category of human law, which could be considered an independent natural principle that poses the danger of becoming superior to divinely revealed law.

John Selden (1584-1654) was not a Jew, but he is credited with arousing interest in the natural law theory within Judaism. He argued that a theory of natural law could be identified in the Noahide Commandments. These laws, which are relatively unknown outside of Judaism, were considered to contain important theological principles, which is confirmed by the fact that they were elevated to the dignity of rabbinic debate. ${ }^{5}$

\section{Distinctive Characteristics}

The Seven Laws of Noah are also known as the Noahide (Noahite) Laws. ${ }^{6}$ They are a set of laws that the rabbinic tradition considers important as the minimal moral duties that the Bible enjoins on all men. ${ }^{7}$

The Seven Laws contain specific prohibitions that make up the Noahide Laws; they are prohibitions against idolatry, blasphemy, bloodshed (murder), sexual sins, theft, eating flesh from a living animal, and an injunction to establish a legal system. The titles are derived from Midrashic and Talmudic sources. ${ }^{8}$ Although the expression "Noahide Laws" intimate that the laws were given to Noah, this is somewhat

4

Jeffrey Macy, Natural Law, 664.

Cf. Babylonian Talmud (BT) Sanhedrin 56a-59b; Tosef. AV. Zar. 8:4; Dictum BT Yoma 67b 7; BT Enuvin 1006. The first talks about keeping those commandments, which should have been written, even if they had not been included in Scripture by right. The second states: "If the Torah had not been given, we could have learned modesty from the cat, aversion to robbery from the ant, chastity from the dove, and good manners from the cock."

In Hebrew: Sheva Mitzvot benei Noach.

San. 56-60; Yad Melakhah 8:10, 10:12.

Reproduced in the Tosefta; a work commonly believed to have ben edited late in the second century A.D. Av. Zar 8:4; Sanh. 56a. 
misleading because the laws were derived exegetically from divine commands addressed to Adam and only later re-established with Noah. ${ }^{9}$ As such, the message takes on a universal dimension as Adam Biblical Hermeneutics represents humankind and serves as a point of theological contact with those outside of the Jewish Covenant.

A non-Jewish person who accepts the prohibitions of the Noahide Laws has a particular identity within Judaism. Every non-Jew is considered to be a son of the covenant with Noah (Gen. Ch. 9) and becomes a ger-toshav, a resident stranger, or a semi-convert. The ger-toshav has the full support of the Jewish community and is entitled to full material assistance; ${ }^{10}$ he is obliged to fulfilled certain prescriptions and is penalized by the Jewish authorities for breaking the Jewish Code of Law.

For a non-Jew, the critical status of the Noahide Laws and their theological implications can contribute to a more effective and focused examination of the textual evidence, especially the way in which they developed in relation to the laws given at Sinai.

The status of a Noahide Gentile implies that there is, in fact, a distinction between a Jew and a Noahide within Judaism. This starting point best reflects the Orthodox Jewish view, which upholds that a Noahide Gentile also accepts monotheism and understands that unity is found in God Himself. This shared Jewish belief serves as a bridge that opens the way to dialogue and creates an atmosphere in which suspicion may be set aside. ${ }^{11}$ Consequently, dialogue takes place within the overall context of Judaism and, therefore, can grow and develop without fear of contamination and uncleanness. In this context the Gentile Noahide and Orthodox Jewish communities can co-exist because they have become "co-religionists," striving for the same end. The Gentile Noahites are, therefore, an "incorporated people" within the Jewish nation's life and can show solidarity not only in their religion but also in a relationship of "Peoplehood" with God. The non-Jew is now within the community of the Jews, and the same God may be found on each path: "The One God is found on both paths because the One God gave both. The Noahide laws define the path that God gave to the non-Jewish people of the world." ${ }^{2}$ The paths

$9 \quad$ Gen 2:16. This idea is reenforced by the article "Noachide Laws," Encyclopedia Judaica, vol. 12, , 1190.

Sefer Hasidim 1957, 358.

11 The laws are also commandments. In Hebrew the word "mitzvah" also means connection.

12 "Laws of Idolatry," Chapter 8. Law 11, Mishnah Torah. 
Biblical Hermeneutics

on which both communities tread on their way to God, however, are not strictly the same.

\section{Theological Principles and Reward}

The theological status of the Noahide derives from the Commandments themselves. The Mitzvahs, which mean "to attach or join," unite the Noahide to God's will and wisdom, and it is from these that a person will receive light for his soul. This light is eternal, and through it, the soul earns an eternal reward. The Gentile fulfills the purpose of God's creation and receives a share in the world to come-the blessed spiritual world of the righteous. ${ }^{13}$ As Clorfene and Rogalski explain, preparation for this world occurs through the Gentile's acceptance of the rabbis' teaching, since this is the primary source of the Commandments: "The source of understanding the Seven Noahide Commandments is found in the Talmud and later rabbinic teachings and nowhere else." 14

The influence of these laws within Orthodox Judaism is limited. One of the reasons for this is simply a dislike of the idea that the Noahide Laws could serve as a textual basis for a theory of natural law in Judaism. Current Orthodox tradition does not tolerate a form of law that is anything other than revealed. Throughout the ages, Maimonides' teaching and personal dislike of natural law have overridden the voice of critical historical research.

\section{The Place of Noahide Laws in the Scriptural Tradition of Israel}

Now we can confidently assess the development of Noahide Laws within a textual and extra-textual context. An analysis of the laws themselves will demonstrate the basis of a theory of natural law within Judaism.

We begin with the Mishneh Torah, a collection of oral traditions that contains a pattern of events that lead directly to the establishment of the Noahide Laws in the tradition of Israel. Here we find the teaching that the laws were given to Adam, and he was enjoined to teach them to future generations. The teaching develops to press the point that it was unfortunate that man failed to keep God's laws or impart

13 Chiam Clorfene and Yakov Rogalski, Path of the Righteous: An Introduction to the Seven Laws of the children of Noah, 4.

14

Ibid, 5 . 
them to others as he developed under God. God sent the flood to destroy the world because of man's failure to keep the law. Yet, before the destruction of the world by the flood, God singles out Noah as the Biblical Hermeneutics people's new leader. Noah is chosen because he remained faithful to God's Law and "walked with God." 15 God rewards Noah for his fidelity by establishing a covenant between Himself, Noah, and Noah's children. ${ }^{16}$ However, Noah notices one thing that is missing that troubles him: God had walked with Adam in the garden. For this reason, Noah wishes to re-establish the Divine Presence on earth.

In an amusing scene, Noah tries to tempt the Divine Presence back to earth with a beautiful vineyard, ${ }^{17}$ but Noah only succeeds in getting drunk on the wine. The Talmudic tradition suggests that Noah's drunkenness in the vineyard carries on Adam's disobedience and shame; as a result, the Divine Presence chose not to dwell in the vineyard. At this point, it is tempting to think that God will destroy Noah and the Noahide Law with him. Instead, God, mindful of His postdiluvian covenant, looks down with pity on Noah, ${ }^{18}$ and both he and the laws are given a secure future. Noah's descendants are entrusted with the responsibility to teach the law.

The Seven Commandments of the Children of Noah remained, as before the flood, unheeded by all but a few, notably Shem and his grandson Eber, who established Houses of Study for the purpose of understanding and fulfilling the Noachide Laws. ${ }^{19}$

A severe decline in the people's behavior, as exemplified in such stories as the Tower of Babel, Sodom and Gomorrah, and witcheraft, ${ }^{20}$ seriously damaged their relationship with God. Eventually, a righteous man was raised up-Abraham, who stood alone against the world, clinging to the Creator and the fulfillment of His will. Thus, the People of God came into existence. The generations of Abraham, Isaac, and Jacob brought honor to God and the Children of Israel through them. Through Abraham, a legal thread links the past, present, and future in the Noahide Laws. After Noah, the Patriarchs revere the Laws of Noah

\footnotetext{
$15 \quad$ Gen 6:9.

16 Gen 9:12-13.

17 Gen 9:20-21.

19 Rashi's commentary on Genesis, 25:22. Rashi is the popular Jewish name for Rabbi Schlomo Yitzhak (1040-1105), the author of the greatest commentary on the Humash (The Pentateuch). 
Biblical Hermeneutics

Laws of Noah and treat them as an essential part of the progression towards the Commandments revealed on Sinai. The Noahide Laws are not to be forgotten because they are part of the tradition.

Such commentaries can be found in early Jewish theological writing. The French Rabbi Shlomo Yitzchaki (1040-1105), also known as Rashi, proposed that Abraham, Isaac, and Jacob knew that their descendants would go to Egypt, be redeemed by God, and given the Commandments. He states that these ideas were maintained through the gift of prophecy:

The Patriarchs fulfilled the Seven Commandments of the Children of Noah, and through their gift of prophecy, saw what the Sinai Revelation would bring and obeyed those laws as well, even though they had not been commanded concerning them. ${ }^{21}$

Rashi's commentary points out the unique relationship between the Noahide Law and the Sinaitic Law. Rashi's use of biblical texts points to prophetic foresight of the future Code at Sinai: "Because Abraham listened to My voice, and kept My charge, My commandments, My statutes, and My laws."22 Such texts reinforce Rashi's theory that reference the word "charge" is considered equivalent to the Torah, which God had not yet given.

Although the Code is not mentioned directly in the biblical text, it can be discerned in some conflicting interpretations regarding legal observance. There is reason to suggest that the Noahide and Mosaic Codes existed side by side and were accepted as different traditions. A primary example of this is cited in the conflict between Joseph and his brothers, which has to do with the difference between the Mosaic and Noahite dietary laws. Mosaic tradition says that the flesh of a ritually slaughtered animal may be eaten even if the animal moves after it is slaughtered. At the same time, the Noahide law does not require ritual slaughter, but it forbids the eating of the flesh of an animal until it has ceased to move after being slaughtered. Joseph observed his brothers following the Mosaic precept and reported it to his father. ${ }^{23}$ Joseph believed that his brothers had erred and acted on his belief. The consequences for Joseph were dramatic: he was sold into slavery in Egypt. The captivity in Egypt was a significant period of preparation for the Revelation at Sinai and the giving of the Torah. ${ }^{24}$

\footnotetext{
21 Rashi, Commentary on Genesis 26:5.

22 Gen 26:5.

23 Gen 37:3.

$24 \quad$ Ex 24:10.
} 
With the giving of the Torah, God chose a people to live by His Commandments. This is a critical moment for those who believe that revelation is the only authentic expression of law. Such individuals think Biblical Hermeneutics that the Revealed Law predominates and that the Noahide Laws are absorbed into the Mosaic Laws, thereby losing their independence. This unification of the two sets of law during the revelation at Sinai strengthened and confirmed (rather than diminished) the obligation for non-Jews to follow the Noahide Laws. Righteous Gentiles were obliged to follow the Seven Commandments and, by association, the Sinaitic Commandments because the Noahide Laws were now considered subsumed into the Sinai Laws. This did not alter the distinction between the two sets of people who followed the respective laws. Unfortunately, a distinction within Judaism between the convert and the born Jew has always existed. From the time when the Jews finally settled in Canaan until the time of the Jewish Diaspora, Gentiles who wished to dwell in the land had to fulfill the Noahide Laws. Once this had been accepted, the Noahites could enter the Temple and offer sacrifices to God. ${ }^{25}$ The relationship between the Noahites and the Jews would always be similar to the relationship between a priest and a faithful layman. ${ }^{26}$

The obligation to follow the Noahide Laws was incumbent upon the Jews from Adam to the Revelation at Sinai. Virtually all Jewish thinkers who dealt with this issue kept this in mind.

\section{Specific Differences Between the Two Laws}

It would be a mistake to imagine that the Noahide Laws lost their influence after the Torah was given at Sinai. The differences in the two parallel laws illustrate this. The Noahide Law concerning idolatry declares that non-Jews do not have to know God but must declare themselves against false gods in order to ensure social stability. ${ }^{27} \mathrm{Un}$ like the Jews, Noahites were not expected to die for this law. Still, the obligation to suffer "martyrdom" is present in the law against murder (see the Pesahim, Book of the Passover 25,b), where it is written that an individual should undergo martyrdom rather than shed another

\footnotetext{
$25 \quad$ Zec 14:17-18.

26 BT Sukkah 52b.

27 Megillah, also known as The Book of Scrolls, is concerned with Purim, the feast of deliverance of the Jews from destruction in Persia as narrated in the book of Esther.
} 
Biblical Hermeneutics

person's blood..$^{28}$ The Noahide Laws concerning blasphemy, murder, and theft are stricter than those codified from the Sinai tradition. This gives the impression that the penalties for a Gentile convert are more severe than those for born Jew. The explanation for this is that moral laxity was considered to be more prevalent outside Judaism and, therefore, more likely in the culture of the Noahide convert, and be more challenging to overcome. The prohibitions against theft, which covers many acts from military conquest to dishonesty in economic life, also support this idea and demonstrated the need for much more dissuasive and wide-ranging regulations. ${ }^{29}$

By acknowledging the two sets of law, one of which defines the behaviors of the Gentile convert, Jews were obliged to establish the Noahide Code wherever and whenever they could. The Noahide Code indicated that courts should be established to implement the Code and punish those who did not keep it. By establishing these courts, the Jews accepted the differences between themselves and non-Jews in legal practices. However, when the courts recognized essential normative similarities within non-Jewish societies, the judges issued more lenient and tolerant judgments based on broad consensus. The judges did not try to synthesize the two codes, but they did recognized certain elementary standards that made interaction between the two "communities" possible. In other words, there was a system that acknowledged the place of the Noahide Law in Jewish life.

\section{An Implied Theory of Natural Law}

A fundamental element for consideration in any theory is the individual's natural inclination to make moral norms and reach a theory of natural law. If the Noahites hold themselves accountable to the law, and if Jews are not obliged to enforce it, then this implies that lawfulness is not something that Jews impose upon non-Jews, but rather inherent in humanity itself. In pre-Sinaitic times, human lawfulness is perceived as a necessary prerequisite for the emergence of Judaism. This leads to the conclusions that Jews are empathetic to the idea that all nonJews are Noahites, but those who accept the obligations of the Code are rewarded in a particular way. The respect for Noahide Law that exists at this stage of legal development is but a short step away from acceptance of an independent non-Jewish law in order to establish a moral standard to be applied in regulating Jewish life itself: "There is

\footnotetext{
$28 \quad$ Book of the Passover $-25 \mathrm{~b}$. 
a tacit recognition that Jewish Law and non-Jewish Law have enough in common to allow non-Jewish jurisdiction to have validity in some cases involving Jews." ${ }^{30}$ Add to this a somewhat grudging acceptance: "Gentile moral standards are the minimum but not the maximum in Jewish Law." 31

The universal application of a code that regulated the conduct of "aliens" living within an established religious culture was not unique to Judaism. A precedent may be found in the Roman legal system. The Roman corpus of law known as the Ius Gentium governed cases in which either one party was not a Roman citizen or both parties were resident aliens. All men followed this body of law by virtue of natural reason, and this law differed from the Ius Civile, which was the law of a particular nation.

The Stoics believed that the entire universe is governed by laws that can be comprehended by perfected human reason because these universal natural laws exhibit rationality. They believed that it is possible for a rational human being to understand and act according to natural law. When a person acts accordingly, he becomes a member of one cosmopolis - a political community of the cosmos. In this societystate, all that matters is the attainment of wisdom, as this makes for a perfect society based on the laws of nature.

The Stoics and other Hellenistic writers influenced the Jewish writer and thinker Philo. He develops the argument for a natural law by asserting that the Law given to Moses on Sinai was based on the laws of nature. Philo argues that

the world and the law are in mutual accord, and that a man who is law-abiding is thereby immediately constituted a world citizen (cosmopolite) guiding his actions correctly according to nature's intent, in conformity with which the entire universe is administered..$^{32}$

These ideas most certainly circulated throughout a large part of the Greco-Roman Empire. It is difficult, therefore, to imagine that Jewish thinkers and writers could be ignorant of a philosophical concept known as far back as Cicero and that played such an essential role in the Western Latin tradition of Europe.

The ad silentium argument for the absence of natural law in Jewish writings does not necessarily mean that the concept was ignored or not

30 David Novak, Image of the Non-Jew in Judaism: An Historical and Constructive Study of the Noahide Laws (New York: Edwin Mellen Press, 1983), 67.

$31 \quad$ Ibid, 74 .

32 Philo, On the Creation of the World, 1, 3. 
Biblical Hermeneutics

taken seriously within Judaism. The rabbinic and normatively binding Halakhic prescriptions, which include prohibitions against acts of public nudity, the eating of human flesh and rancid carrion, and the obligation to look after and support one's infant child, which are all acts governed by natural law, demonstrate the continued implementation of natural law theory. These prohibitions also indicate a particular affinity with the obligationes naturales of the Roman law rather than biblical command or rabbinic legislation.

There were two essential sets of laws, one of which was for "nonJews"-a title so given because there was no religious/national identity at that time that gave non-Jews the benefits of status, unity, and "righteousness." The second set of law was given at Sinai and served as an affirmation of all past laws and as an acceptable way of life for the future. Before the Law of Sinai was given, the older Noahide Law was respected and followed by all and became the law that governed the status of a convert. Both sets of laws are complementary, and likely interchangeable in some areas. Interchanging the laws took place gradually in the teaching of certain rabbis and, in particular, Moses Maimonides. These rabbis argued that the Noahide laws were subsumed or surpassed by the prevailing Laws of Sinai. Either way, the Noahide Laws did not cease to be an accepted legal code. Outside of Judaism, similar sets of laws that referred to the actions of those who were not full members of a given social group or community also existed. It is possible, therefore, that these other laws influenced the application of the Noahide laws and passed on a theory of natural law to Judaism.

If the Noahide Laws are universally applicable to both Jews and non-Jews, then this implies that natural law lies at their heart because man arrives at and identifies law through his moral nature.

\section{Nature and the Individual}

Since a person can arrive at and identify a law through his moral nature, this debate can take place on a more speculative philosophical level. "Despite the absence of a specific reference to natural law in Biblical literature... there have been Jewish thinkers who have argued that natural law [is] implicit in the Noahide Commandments." 33

A theory of natural law is based on the fundamental assertion that a human being comes to a knowledge of what is right and wrong through non-mandatory means. Individuals have a natural disposition,

$33 \quad$ Jeffrey Macy, Natural Law, 58. 
for example, to honor their fathers and mothers; not to steal; not to murder. Five of the Noahide laws fall within this category; in other words, these laws would have been mandatory even if they had not been revealed because they arise from natural law. ${ }^{34}$

The law that prohibits eating a "torn limb" from a live animal, which was the reason why Joseph incurred the wrath of his brothers (Gen 9:4), was brought up in discussions that aimed to formulate opinions during the Talmudic period regarding whether or not the Noahide Laws were a formulation of the natural law.

Nature is non-human created order that was fully complete before man came into existence. To avoid the danger of becoming an alien in the world, humankind must understand nature's ways and patterns. A human being must seek to live by observing the order of nature and avoid disturbing it. Both the Ancient Near East and Noahide tradition agree that, apart from mitigating circumstances, it would be unnatural to tear the limb off of a living animal for food! Prohibitions against castration, eating blood, and crossbreeding arise from this philosophical viewpoint. Rabbinic texts also support this reasoning. When Rabbi Eleazar was asked from where he derived his prohibition against crossbreeding, he replied: "Samuel says that scripture states, 'My statutes you shall observe' (Lev 19:19). Namely statutes I have already made for you... My statutes you shall observe; statutes which you were originally to observe." 35

Rashi's interpretation is directed towards the statutes initially observed by the Noahites, while the Spanish Rabbi Meir Abulafia (1170 - 1244), also known as Ramah, interprets the statutes as that from which the world is so ordered that creation cannot change. In other words, the Noahide Laws are not random decrees from an earlier generation but rather natural laws. To violate such laws is to infringe on the natural created order of the cosmos. ${ }^{36}$

If violation of natural law is an infringement on the natural created order of the cosmos, then this universalism presupposes a "general righteousness" found among human beings. It is the pattern to which they are called to conform. This participation in "general righteousness," may lead, in turn, to participation in the new world to come:

\footnotetext{
$34 \quad$ Yoma 67b: Sifra Aharei Mot 13:10.

$35 \quad$ Sanhedrin 60a. Rashi, 99.

$36 \quad$ This idea is found in Philo, De Spec. Leg. 4.204:136-137. See Palestinian Talmud (PT); Nahmanides systematically expresses this idea in Ramban to Leviticus: $120-121$.
} 
Biblical Hermeneutics

"All the righteous men of the nations of the world have a share in the world to come." 37

The fundamental nature of the text is contained in the latter half that states "a share in the world to come," which is perceived as similar in meaning to the Christian term "to be saved." If the passage can be interpreted to mean that those who are not Jewish may be saved, then a further question must be asked: Who can be saved? The text supplies the answer: Those who lead a morally righteous life. If we interpret the text in this way, which implies universal righteousness available to non-Jews, then we have also made a bold interfaith statement. It means that it is possible for those outside of the revelation of the law from Sinai receive salvation. Jewish scholars, especially those who follow Orthodox Judaism, do not readily agree on this concept. They refuse to accept that the Noahide Laws can stand on their own merit without the ratification of revelation. For, these laws have to be accepted and practiced because they were commanded by God and ratified by Moses. Outside of this, if a person obeyed the laws, or adheres to them through rational thought, then such a person may not be counted among the righteous.

\section{The Influence of Moses Maimonides}

Moses Maimonides is the leading opponent of a natural law theory, and his view frequently appear in his texts. On a superficial level, it is easy to see why he is against natural law: He disparages what ought to be done through reason and promotes the idea of law based upon revelation. However, he does not preclude rational explanations for the law or showing that a worthwhile end to be achieved exists. "For Maimonides, laws are true by Divine sanction, but reason discovers their wisdom and intelligibility." 38

Moses Maimonides tries desperately to lay to rest the theory that states that, although human beings are to abide by the Noahide Laws (Sanhedrin 56a), anyone who conscientiously carries out these laws is potentially righteous. He argues that the natural progression of this theory is to claim that one can know the right course of action and follow it without the benefit of any Jewish revelation. Further, natural law adherents would not be concerned if the righteous Gentiles based their adherence to the laws on something other than reason. In this,

37 Tosefta Sanh. 13:2b; Sanh. 105a.

38 Isadore Twersky, Introduction to the Code of Maimonides (Mishneh Torah) (New Haven: Yale University Press 1980), 457. 
the essential point is missed: there is no natural law in the Noahide Code. Individuals must base their adherence to the law on revelation. Therefore, Maimonides wishes to attribute all law to solum per revelaBiblical tionem. Everyone who accepts the Seven (Noahide) Laws and is careful to fulfill them is one of the righteous, if he accepts and practices them on the grounds that God commanded them in the Torah and informed us through Moses our teacher that the sons of Noah (Noachites) had earlier been given these commandments. But if he practices them on the basis of his own rational considerations, then he is not a resident stranger/convert, not one of the righteous men of the nations of the world, not one of their sages. ${ }^{39}$

Maimonides develops his argument in "The Laws of the Kings." The text by Maimonides quoted above contains his main objection to Noahide Law and rational consideration. The ambiguity of the italicized portion of the text has fuelled controversy and debate; for those who believe in a theory of natural law, the "righteous man" will see by the light of reason that these laws are good in themselves, and a human being, may or may not believe that they have their source in any individual, human or divine. Maimonides accepts that a person who follows the Noahide laws is righteous and has a place in the world to come, but this is the case only if the same person accepts the Noahide Laws under the condition that Moses ratified them and God commanded them in the Torah. In this way, Maimonides singles out reason as the archenemy of revelation and continues his argument by attacking it as means to arrive at the acceptance of the judgments contained in the Noahide Laws. The penalty for not recognizing these views are, as might be expected, forfeiture of the benefits of righteousness. As the text declares: "But if he observes them because of his conclusions based on reason, then he is a resident alien and is not one of the righteous of the nations of the world, nor is he one of their wise men." 40

Maimonides' opponents employ both textual material and philosophy in their arguments. Steven Schwarzschild suggests a three-point plan to analyze Maimonides' argument critically.

a. From where in Jewish Law does Maimonides derive his doctrine?

b. Why does he stipulate it?

c. What are its implications? ${ }^{41}$

$39 \quad$ Moses Maimonides, Laws of the Kings 8:11.

40 See the translation of Laws of the Kings (Mishneh Torah - M. Maimonides) in Marvin Fox, "Maimonides and Aquinas on Natural Law," Dine Israel 3, 5-36.

$41 \quad$ Steven S. Schwarzschild, Jewish Quarterly Review, vol.5 (2), no. 4 (April 1962): 301. 
Biblical Hermeneutics
In response to the first question, Maimonides may be criticized for not specifying his sources when analyzing Noahite Laws in light of texts from the Mishna Torah. Thus, the materials to which he referred when assessing Noahide Laws cannot be traced. Maimonides' independent thought may be criticized not because it is right or wrong, but because his thought derives no authority from the Talmud. ${ }^{42}$

Alternatively, some scholars disagree with Maimonides' methodology and lack of Talmudic authenticity. ${ }^{43}$ Schwarzschild considers Maimonides' lack of Talmudic authority a grave impediment: "Whether he is philosophically or theologically right or not, legally, so far as Judaism is concerned, he would seem to be taking an almost untenable position." ${ }^{44}$

Unfortunately, a great limitation when researching Maimonides' references is the fact that such investigations did not begin until after he died. This means that, although certain passages and words might be found in one text, the same wording often appears in different contexts in other rabbinic texts. The deceased Maimonides cannot specify his textual points of reference, so genuine source material remains a matter of speculation. ${ }^{45}$ For instance, the text of the Mishneh Tora, which Maimonides uses, is not quite the same as an early version of the text found in the Bodleian Library, Oxford. Between Maimonides' citation and the early version there is a discrepancy in the last few words; the Bodleian version contradicts Maimonides' citation by using the Hebrew word ELA instead of VELO. This changes the meaning of the text, which now reads: "neither a resident convert/stranger nor a Noachite but one of their sages."

In an attempt to uncover references further, other scholars trace them to their historical sources. This approach is problematic, as can be seen in an obscure midrash given by R. Solomon ben Isaac of Wolosin quoted in Toledot Adam by Ezekiel Feival ben Zev. Ben Zevtries to give a precise reference for the text, which such scholars as R. Hirsch Chajes and Steven Schwarzschild refute as spurious proof.

42 Moses Mendelssohn, "Letter to Lavater," in Gesammelte Schriften Jubilaemsausgabe, vol. 7, 11.c. See also Rabbi Joseph Karo's commentary Kesef Mishneh.

43 See Joseph Karo's commentary Kisef Mishneh.. Moses Mendelssohn and Herman Cohen quote the Lechem Mishneh to the same effect. See also Spinoza, Ueber staat und Religion, Judentum und in Jüdische Schrifen, 346.

$44 \quad$ Ibid, 304.

45 D. H. Joel attempts to do this by using later source material, e.g., Toldot Adam, ref. $6: 35 \mathrm{a}$. 
Michael Guttmann ${ }^{46}$ attempts another approach by uncovering a source that seems to reflect Maimonides' view. ${ }^{47}$ The problem is that the text could so easily be the work of a later scribe who interpolated Biblical Hermeneutics a passage from Maimonides. The only positive connection is the fact that Maimonides cites the Mishnat of R. Eliezer in two of his works: Sefer Hamitsvot and Responsa. This provides a much stronger argument for a definite source for Maimonides' view, but the theory lacks proof. In such a case, the argument remains speculative. Those on both sides of the textual argument make the valid point that the copyist would have translated the text according to his personal view: "Thus the copyist impressed by his 'rationalism' would read it as 'but,' and those otherwise inclined would read it as 'not,' and so textual arguments about which texts are preferable are unlikely to be profitable." 48

\section{Influence of Classical Islamic Philosophy and the Philosophy of Maimonides}

Sources outside the main Hebrew text may help shed light on Maimonides' position. ${ }^{49}$ As a philosopher, Maimonides would have read much of the great philosophical writers. He even argues that one of his great "teachers," Aristotle, was not able to attain salvation because he embraced the dictates of reason and "not as of Divine documents prophetically revealed." 50

A leading Jewish writer, Oliver Leaman, suggests that classical Islam considerably influenced the place of reason in Maimonides' philosophy. ${ }^{51}$ The fact that Maimonides was accepted as an Islamic philosopher demonstrates that his thoughts conform to those of mainstream Islam.

In classical Islam, a theory of natural law did exist. However, as in Judaism, it had its proponents and antagonists. A strange comparison can be made between Maimonides' position and his Islamic predecessors who also disliked natural law theory. A primary example is seen in the work of $\mathrm{Al}$ Ghazali.

46 Michael Guttmann, "Zur Quellenkritik des Mischneh Thora," Monatsschrift für Geschichte und Wissenschaft des Judentums, vol. 79, no. 2 (1935): 148-159.

47 See Mishnah of R. Eliezar, The Midrash of Thirty-Two Hermeneutic Rules.

48 Ibid, 80.

49 Maimonides is regarded as an Islamic philosopher. He was known as Mise b. Maymin.

50 Theological/ Political Tractate, vol.1, trans. Elwes, 80.

51 Ibid, 89-91. 
Biblical Hermeneutics

The notion of obligatory acts (Wajib) is equated with God's command and rewarded accordingly. This notion is present in the doctrine of the Sunnite legal tradition established by Shafi ${ }^{52}$ and Ibn Hanbal ${ }^{53}$ and supported by Ash'ari's theology. ${ }^{54}$ This idea stands in opposition to the Mu'tazilite ${ }^{55}$ idea that certain acts were obligatory due to the properties of the acts and that God insisted they were requisite because of the sorts of acts they were. Some moral properties of actions are subjective and apply to certain kinds of phenomena in the world. Classical Islam argued that no act is obligatory in itself; that God has no purpose in particular human welfare; and that we can know nothing of our obligations through the independent use of reason, regardless of the aid of revelation.

The Mu'tazilite tradition comes close to natural law theory rather than a doctrine of ethical subjectivism, but Maimonides definitely distances himself from it, preferring Al-Ghazali's view that moral propositions are subjective and only obligatory if commanded by God. ${ }^{56}$ Another difference in philosophical principles that suggests that Maimonides at least acknowledged reason and gave it a place in his thought is this: "Maimonides does not think that normal propositions are non-cognitive. The final end of human beings is contemplation, but the acquisition of moral virtues is a sine qua non for such a life." 57

In Judaism, moral opinions may regulate political life and prepare individuals for a final perfection are generally accepted; this is often described as theoretical knowledge of things as they really are. Within the process of constructing moral opinions for this purpose, an argument that suggests that rationality plays a part in the application and discovery of opinions exists.

To be sure, the reasoning involved would be of a lower order than the reasoning which characterizes pure contemplation, but it would still qualify as reasoning. The results of the reasoning, the moral opinions,

52

Shafi'i was a leader of a school of law named for him. Shafi'i emphasizes 'analogy' in interpretation of Islamic law.

Ton Hanbul was the founder of a legal school that worked strictly within the framework of the Koran and Islamic tradition (Sunna).

Ash'ari was the strongest opponent of the Mu'tazilite school. He held a literal interpretation of the Koran as well as its 'uncreatedness.'

The Mu'tazilite theological school of Islam was the first to use reason and dialectics as a tool for theological debate. This school fell afoul of orthodox Islam by upholding that the Koran was created.

Mn. 111, 17, 469-471

Ibid, 90 . 
would be objective in the sense that they would accurately describe how people could live together successfully; that is all that we can expect from a law which is not divine. ${ }^{58}$

The Age of the Enlightenment's contribution, particularly to the reawakening of the importance of nature, was the most significant step forward in the debate concerning natural law in Judaism. The Enlightenment reassessed the power and the dignity of creation and man's place within it. Before the Enlightenment, creation was considered a mystery. As a result of the Enlightenment, creation became the symbol of the unified rational cosmos of law and order. This evaluation of creation was a short but significant step towards a theory upholds that, if nature represents God's perfect order, then what is natural must also be considered reasonable.

This new and initially shocking philosophy had the immediate effect of polarizing thinkers into radical and traditional camps. Not all, however, took an extreme position. Some thinkers tended to be conciliatory in their views, and this was true for religious thinkers and philosophers both within and outside Judaism. If the laws of reason could be found in all areas of endeavor, then could it not be found in religion too? While the answer to this question seems like commonsense, the danger rests in the methodology used in philosophy, which the Jewish scholar Noah Rosenbloom points out: "All that was necessary was to divest the historical religions of their accidental elements, superstitious accretions, and sacerdotal practices, and a rational religion would emerge." 59

Inevitably, the arguments in favor and against natural religion hinge on the criteria that undergird them. What constituted a rational religion was not that difficult to find: whichever religious ideas and values could be discovered in nature ought to be considered natural religion, or the religion of reason. When this approach is taken to its logical conclusion, then the idea of the bon savage was closest to universal reason, eternal truth, and natural religion. It is no wonder, then, that opponents to this idea tried desperately to find a higher synthesis. They attempted to identify Christianity with the principles of the religion of reason and, subsequently, with those of natural religion. The consequences of this philosophical trend are still felt today and are the basis of the arguments of those who oppose formal worship or organized religion.

$58 \quad$ Ibid, 90 .

59 Noah H. Rosenbloom, Judaism and Natural Religion, 161. 

Biblical Hermentics into Eighteenth-Century Society

Noahide Laws and Jewish Integration

The effects of the Age of Enlightenment were not limited to Christianity. Judaism was also hotly debating the new philosophy but with an added incentive. During the New Age, many European Jews were keen to emerge from the ghettos and take part in a more integrated society. The Noahide Laws "extend beyond their intrinsic, halakhic, and theological aspects[; t]his makes them ready for an important role to play in the political and social conditions of the Jews of Europe during the period of the Enlightenment" ${ }^{60}$ as a ready-made link that bridges the gap between the two communities.

If the voice of Judaism was to be heard and the Jews themselves accepted into society, then the Jews had to extend the same openness to the Gentiles. The Noahide Laws were a means by which this contact could be achieved, and so the discussion concerning the implications of the Noahide Laws both for Jews and Gentiles resurfaced. In particular, the thoughts of Moses Maimonides were debated within a much broader forum:

In an age which theological discussions dominated the intellectual scene, the question whether Judaism accepts the Talmudic principle, "All the righteous men of the nations of the world have a share in the world to come," is a crucial one in the struggle for emancipation. ${ }^{61}$

The Jewish philosopher Baruch Spinoza (1632-1677) questions his alleged illiberal views, the challenge to Maimonides's argument. Unfortunately, Spinoza's answer was proved to be superficial in two significant ways. First, Spinoza uses a corrupt version of Maimonides' text to argue his point. Second, although Spinoza is an original thinker and philosopher, he is no match for Maimonides' Jewish scholarship. Spinoza's conclusions are based more on speculation than fact. $\mathrm{He}$ summarizes the thrust of Maimonides argument by saying that those who keep the commandments on rational grounds as basic ethical precepts following from human reasoning may be called "wise" but not pious, and, therefore, not entitled to the reward in the life to come.

Even though Spinoza's arguments against Maimonides are shallow, this did not distract from Spinoza's far-reaching influence. His counterarguments against Maimonides became the source of a series

60 Jacob, "Natural Law in Maimonidean Thought and Scholarship," Jewish Law Annual, vol.6 (1987): 64.

61 Jacob 1 Dienstag, "Natural Law in Maimonidean Thought and Scholarship - On Mishneh Torah, Kings VIII," Jewish Law Annual 6 (1987): 65. 
of misunderstandings in the Jewish religion. This is particularly true in German literature and thought. Kant gleaned his knowledge and evaluation of Judaism from Spinoza, while Leibnitz (1646-1716) valued Maimonides' philosophy. was After reading Spinoza, Kant concluded that Judaism was rightly condemned. In his famous polemic with the theologian Johann Casper Lavater, an admirer of Maimonides, Moses Mendelssohn continually emphasized his conviction that Judaism is true. He argued that Gentiles who are righteous or pious share in the world to come. Being aware that Maimonides was restrictedly tolerant, Mendelssohn questioned Judaism's exclusive claims to disallow an eternal reward to those who followed the Noahide Law without the light of revelation. He wrote to his friend R. Jacob Emden:

What, then, shall the nations do who are not recipients of the light of the Torah and who received no tradition except from untrustworthy and unreliable ancestors? Does God, then treat his creatures in the way of a tyrant, annihilating them and blotting out their names [by denying them a share in the world to come], though they committed no injustice? ${ }^{62}$

Mendelssohn believed that Noahide Law represented a theory of natural law. Still, he also understood Maimonides' point that moral principles have no true value because they are not subject to any rational demonstration. If there is no revelation, then the only source of morality is social convention. Mendelssohn argues that he has clear and sound demonstrations for good and evil, right and wrong, beauty and ugliness, which shows rational principles. Unfortunately, says Marvin Fox, Mendelssohn never demonstrates them. ${ }^{63}$

A series of scholars and commentators have contributed to the debate. Steven Schwarzschild follows Mendelssohn's argument. He finds that, even though the text is amended, there is still the unresolved problem of exclusiveness:

He excludes what [he] might call the philosophical rather than the religious Noahites from the righteous men of the Gentile nations of the world and thus from the world to come. All questions previously raised with respect to this dictum, therefore, retain their validity. ${ }^{64}$

\footnotetext{
62 Alexander Altmann, Moses Mendelssohn, 215.

63 Marvin Fox, "Law and Ethics in Modern Jewish Philosophy: The Case for Moses Mendelssohn," P.A.A. JR. 43 (1976): 10-12.

64 Steven S. Schwarzschild, "Do Noachites Have to Believe in Revelation?” Jewish Quarterly Review 52, no 2 (1962): 302.
} 
Biblical Hermeneutics

There is a problem in trying to find the relevant sources for Maimonides's arguments. Schwarzschild dismisses R. Jacob Emden's idea that there is a Talmudic source as well as Hermann Cohen's argument against Spinoza as full of personal prejudice, "Spinoza was the archenemy to Hermann Cohen... Spinoza's attack on Maimonides and through Maimonides on Judaism as a whole had to be annihilated at all costs."

Schwarzschild also disagrees with Spinoza, but he does not use personal and vehement attacks of Spinoza as a basis for his arguments like Cohen. Instead, Schwarzschild's argument is simple: Spinoza was wrong to ascribe to Maimonides' view to all Jewish law. Schwarzschild thinks that both Maimonides and Spinoza believe in the concept of natural law. Cohen, however, obscured the issue by identifying ethics with physiology, which assumes that morality is something that exists rather than can be achieved: "A subsidiary weakness of the doctrine which results from this fundamental fault is that it leads to chaos, for all ethical programs have... invoked the warrant of nature for their particular theses." $" 65$

Jose Faur, who denies the possibility of a natural law theory in Jewish thought, holds the opposite view. He draws his conclusion after making a series of in-depth studies surveying natural law theories from ancient Rome through the Christian Fathers, medieval Jewish philosophers, and the Karaites. ${ }^{66}$

Faur argues that natural law is foreign to rabbinic literature, of which Maimonides is the chief exponent. Divine commandments are imperative only based on revelation, and there can be no distinction between the divine (ceremonial) and rational (moral) commandments. Faur arrives at his conclusion quite abruptly, which makes it sound rather unscholarly. He considers it useless to think about the Noahide Laws as a possible source of a natural law theory. He adds the rejoinder that those who seek to arrive at a theory of natural law from the text have laundered the texts to suit their rational or humanistic theories. Marvin Fox thinks the same, but he reminds the reader that the vast majority of laws were explicitly intended for the Jews. In contrast,

\footnotetext{
65 Jacob I. Deinstag, "Natural Law in Maimonidean Thought and Scholarship," 71 .

66 Jose Faur's survey and arguments are outlined in his two main texts: "Origin and Classification of Rational and Divine Commandments in Medieval Jewish Philosophy," Augustinianum 9 (1969): 299-304, and "Basis for Authority of the Divine Commandments according to Maimonides," Tarbiz 38 (1968): 43-54.
} 
only the smallest part of biblical legislation is universal law intended for the rest of humanity. ${ }^{67}$

\section{Reason Cannot Extend to Morals}

Marvin Fox considers Maimonides' view as the most extreme example of a theory that rejects all claims that reason can extend to the realm of morals. Fox encourages a proper understanding of Maimonides' work to illustrate the reasons why he could not believe in a theory of natural law; why he denied salvation to those who believed that one could arrive at moral knowledge on rational grounds; and why he considered such individuals neither pious nor wise.

Of those Jewish theologians already mentioned, Moses Mendelssohn is the most significant critic of Maimonides on this issue. For Mendelssohn, all truth was rational; all men must have partial access to the highest human good through which the good life can be attained. The Enlightenment influenced his philosophical arguments, which he used to expand his tendency to believe that there was no such thing as progress. Mendelssohn argues his rather startling position on the basis that, if progress were possible, then this would imply that those who lived earlier knew less truth than those who came later. (Mendelssohn may be said to represent the pre-historicist Enlightenment). In this way, Mendelssohn struck right at the accepted roots of Judaism, believing that Judaism itself was not revealed truth but revealed law - the law by which "one particular people was commanded to practice the truth which was, for the rest, accessible and comprehensible to all." 68

Maimonides' argument perturbed Mendelssohn to the point of perplexity:

Maimonides believes that good and evil are positive, statutory enactments (Merfursamot), that they are not rooted or formed by reason. In which case, the only means of relying upon righteousness, wickedness, good, evil, the proper and improper is by conventions handed down by trustworthy authorities from the first recipient of revelation. ${ }^{69}$

Maimonides continues his argument in favor of Noahites believing in revelation by including the theory that when a Noahite acts

67 Marvin Fox, "Maimonides and Aquinas on Natural Law," in Studies in Maimonides and St. Thomas Aquinas, ed. Jacob 1 Diestag (New York: Ktav Publishing House, 1975), 76 -77. gabe, vol.16, ed. Haim Borodianski, 178ff. 
Biblical Hermeneutics

out of belief, he reaches the highest good because the act is what God commanded - God who instituted it and who ordained that His will be obeyed in such a manner. A non-Jew who fulfills the Noahide Laws without knowing that these laws constitute the revealed will of God is incapable of complying with this requirement. Personal fulfillment cannot occur without knowledge of the One who commands or the One who, behind the Commandments, is the Supreme Fulfiller. Without such knowledge, there is only a state of nothingness, of nonbeing, standing in opposition to the state of fellowship with God. Scripture is used to support his thesis: "The wicked shall return to the Netherworld, even all the nations that forget God." ${ }^{70}$ In addition, Maimonides insists that one must have the correct and proper intention when following the laws. This can only be achieved if the purpose of the laws are known, in which case, a Noahite must believe in the revealed nature of the law. Again, reason - and even the recognition of the distinction between good and evil - plays a negligible part in the process. According to Maimonides, it is not a matter of rational intelligence but, rather, convention or statutory enactment. In either case, the good is not achieved through reasoning.

In his book, Treatise on Logic, Maimonides suggests the following classifications within the law:

a. Conventions - things that are known to be true without further evidence (i.e., knowledge that unchastity is repulsive or that repaying a benefactor as much as is possible is appropriate).

b. Traditions - accepted from a chosen person or many chosen people (i.e., a knowledge of what is beautiful and ugly).

Mendelssohn is not impressed by this aspect of Maimonides' teaching and will not be dissuaded in his criticism. He ends with an impassioned plea to his friend R. Jacob Emden: "I have clear and correct evidence that good and evil, righteousness and wickedness, the proper and the improper are in truth rational."11

It is easy to fall into the trap of thinking that the eloquent Moses Mendelssohn was the main scholar who was both critical of Maimonides and provided the definitive perspective on natural law. However, the Jewish scholar Joseph Albo, ${ }^{72}$ who wrote as far back as the fifteenth century, provides an original perspective on the theory of natural law and raises some crucial issues that became the basis of future debate.

\footnotetext{
$70 \quad$ Ps 9:18.

$71 \quad$ Moses Mendelssohn, "Letter to Lavater," $178 \mathrm{ff}$.

72 Joseph Albo (d 1444).
} 
In Albo's theory, there are three types of law: natural law, nomos (conventional law), and divine law. The natural law is known through reason, contains fundamental principles that promote justice, and removes wrongdoing. It has a universal application in that it is for all people at all times and places. ${ }^{73}$ For Albo, natural law is necessary to permit and sustain political associations. He advances his theory by asserting that there need not be a scriptural prohibition against ordinary theft (Baba Metsia 16b), because a prohibition, here, is not founded on hermeneutics, but by virtue of natural law. It is not the only area to be considered. Albo treats murder and robbery in the same manner. Together - theft, murder, and robbery - form the three areas in which legislation based on natural law applies. Albo upholds the tradition of universality in his version of natural law theory in Judaism and strives to show "that natural law has a function: that society may be able to exist among men and everyone be safe from the wrongdoer and oppressor."74

While Albo attempts to explain why reason may legislate against theft, robbery, and murder, his writings contain no evidence that suggests that he sees society's preservation per se as mandated by natural law. He also does not suggest that an individual can become virtuous by following natural law, since the latter is not for the attainment of perfection in the spiritual sense but, rather, confined to moral and political principles for worldly justice and peace.

Extending Albo's thesis, the measures directed to preserve social structures are seen as matters of law rooted in natural law concepts. Maimonides' writing concerning the last Noahide Law, the establishment of courts, is a case in point. ${ }^{75}$ It considers punishment for those who break the other six laws and, as such, is a discussion of the binding force of the law on non-Jews. Moses commands all to accept the Mitsvot given by God to the Sons of Noah.

Those who do not keep the commands are to be put to death. Maimonides adds that they are to be put to death "lest the world becomes corrupt." This point considers the natural law; for, if evildoers are not punished, the very fabric of society would be destroyed. Here a subtle distinction is worth noting: Maimonides, suggests Bleich, does not see the Noahide Law as a product of natural law and must admit that it cannot be a binding obligation based on reason alone. The binding

\footnotetext{
$73 \quad$ Joseph Albo, Sefer ha-lkkarim (The Book of Roots), I.7.

$74 \quad$ David Bleich, “Judaism and Natural Law,” Jewish Law Annual 7 (1988): 15.

75 Helkhot Melakhim 10:11.
} 
Biblical Hermeneutics

force for good deeds in the land is natural law, and the preservation of an ordered society is mandated by reason.

The theories of Albo and many scholars - Jewish and non-Jewish alike - throughout the ages show the extent of the theological and philosophical intrigue that the whole subject of natural law in Judaism sparks. Maimonides' pivotal reflections illustrate that natural law theory is limited in its application and its proof is hotly debated. It would be much easier if natural law was totally excluded from Jewish legal theory. However, the question remains: If reason has been accepted, even in part, then why is it not accepted in a fully developed system of natural law? To answer this question is to bring the entire subject into the context of contemporary debate.

\section{Bibliography}

1. Abrahams, Israel. Judaism. London: Archibald Constable \& Co Ltd, 1907.

2. Altmann, Alexander. Moses Mendelssohn. Alabama: University of Alabama Press, 1973.

3. Baeck, Leo. Judaism \& Christianity Essays. New York: Harper, 1958.

4. Braybrooke, Marcus. Time to Meet. London: S. C. M., 1990.

5. Buber, Martin. Ten Rungs: Hasidic Sayings. New York: Schoken Books, 1947.

6. Clorfene, Chiam, and Yakov Rogalsky. Path of the Righteous Gentile - An Introduction to the Seven Laws of the Children of Noah. New York: Targum Press, 1987.

7. Coleman, Gerald D. Human Sexuality. New York: Alba House, 1992.

8. O'Conner, D. J. Aquinas and Natural Law. London: Macmillan, 1967.

9. Cook, David. Moral Maze. London: S. P. C. K., 1993.

10. Demann, Paul. The Jewish Faith: Faith and Fact Series, 134. London: Burns \& Oats, 1961.

11. Dorff, Elliot N, and Louis E. Newman, eds. Contemporary Jewish Ethics and Morality. Oxford: Oxford University Press, 1995.

12. Feinsilver, Alexander. Aspects of Jewish Belief. New York: Kia Publishing House, Inc, 1973.

13. Fisher, Dr. Eugene J., ed. Studies in Judaism and Christianity in Our Time The Flowering of Jewish Christian Dialogue. New York: Paulist Press, 1990.

14. Flannery, Austin. Vatican Council II The Conciliar and Post Conciliar Documents (Study Edition). New York: Costello Publishing Co, 1975.

15. Finnis, John. Natural Law and Natural Rights. Oxford: Clarendon Press, 1993.

16. Gustafson, James. Ethics. London: S. C. M. Press, 1978.

17. Katz, J. Exclusiveness and Tolerance. New York: Schoken Books, 1962.

18. Kung, Hans. Judaism: Religious Situation of Our Time. London: S. C. M. Press, 1992.

19. De Lange, Nicholas. Judaism. New York: Oxford University Press, 1986. 
20. Lichtenstein, Aaron. Seven Laws of Noah. Second Edition. New York: Rabbi Jacob Joseph School Press, 1981.

21. Meeks, Wayne A. Origins of Christian Morality: First Two Centuries. London: Yale University Press, 1993.

22. Novak, David. Image of the Non-Jew in Judaism. An Historical and Constructive Study of the Noahide Laws. New York: Edwin Mellen Press, 1983.

23. Pawlikowski, John T. What are They Saying about Christian and Jewish Relations? New York: Paulist Press, 1980.

24. Pool, David de Sala. Why I am a Jew? New York: Boston Beacon Press, 1957.

25. Porter, Jean. Recovery of Virtue. London: S. P. C. K., 1994.

26. Salvador, J. Jesus Christ and His Doctrine: History of the Birth of the Church, of its Organisation and its Progress During the First Century. Bruxelles: Societe Belge de Librairie, 1838.

27. Sacks, Jonathan. Faith in the Future. London: Daton Longman and Todd, 1995.

28. Saperstein, Marc. Moments of Crisis in Jewish Christian Relations. London: S. C. M. Press, 1989.

29. Strauss, Leo. Natural Right and History. Chicago: Chicago Press, 1953.

30. Storm, Douglas. Encyclopedia of Religion. Vol. 10. New York: Macmillan Publishing Co, 1987.

31. Wilson, Marvin. Our Father Abraham. Ohio: William B. Eerdmans Publishing Co, 1989.

\section{Articles}

1. Benenson, Peter. "Natural Law and Statute Law." Concilium 5., No. 3 (May 1967): 24- 29.

2. Bleich, David J. "Judaism and Natural Law." Jewish Law Annual 56 (1988).

3. Dienstag, Jacob 1. "Natural Law in Maimonidean Thought and Scholarship - On Mishneh Torah, Kings VIII." Jewish Law Annual 6 (1987).

4. Faur, Jose. "Origin and Classification of Rational and Divine Commandments in Medieval Jewish Philosophy." Augustinianum 9 (1969): 299-304.

5. Faur, Jose. "Basis for the Authority of the Divine Commandments According to Maimonides." Tarbiz 38 (1968): 43-54.

6. Lichtenstein, Aharon. "Does Jewish Tradition Recognise an Ethic Independent of Halakha?" In Modern Jewish Ethics: Theory and Practice, edited by Marvin Fox, 62-88. Columbus: Ohio State University Press, 1975.

7. Fox, Marvin. "On the Rational Commandments in Saadia's Philosophy: A Re-examination." In Modern Jewish Ethics: Theory and Practice, 174187. Columbus: Ohio State University Press, 1975.

8. Fox, Marvin. "Maimonides and Aquinas on Natural Law." In Studies in Maimonides and St. Thomas Aquinas, edited by Jacob 1 Diestag. New York: Ktav Publishing House, 1975.

9. Fox. Marvin. "Law and Ethics in Modern Jewish Philosophy: The Case for Moses Mendelssohn." P.A.A. JR. 43 (1976). 
Biblical

Hermeneutics

10. Gustafson, James M. "Dialogue on the Moral Life." The Economist 3, No. 5 (July/August, 1965): $75 \mathrm{ff}$.

11. Kurzweil, Zvi E, and Noah H. Rosenbloom. "Judaism and Natural Religion. Three Views on Revelation and Law." Faith and Reason Essays in Judaism. Edited by Robert Gordis and Ruth B Waxman. New York: Ktav Publishing House, 1973.

12. Macy, Jeffrey. Natural Law: Contemporary Jewish Religious Thought. Edited by Arthur Cohen and Paul Mendes-Flohr. London: Free PressDivision of Macmillan, 1987.

13. Schwarzschild, Steven S. "Do Noachites Have to Believe in Revelation?" Jewish Quarterly Review 5 (2), No. 4 (April 1962).

14. Secretariat for Promoting Christian Unity, Information Service. Vatican City: 1967/3 p.24ff. Ibid. No 261975 p.6ff.

15. John Paul II. Addresses and Homilies on Ecumenism, 1978-1980. Edited by John B. Sheerin and John F. Hotchkin. Washington, D.C.: US Conference, 1980.

16. World Council of Churches. Current Dialogue, No. 28 (June 1995). 